AGH DRILLING, OIL, GAS • Vol. 32 • No. $2 \cdot 2015$

http://dx.doi.org/10.7494/drill.2015.32.2.369

\author{
Anastasiia Laura*
}

\title{
GEOMECHANICAL PROPERTIES OF SHALE ROCK FROM BALTIC BASIN IN POLAND AREA
}

\section{INTRODUCTION}

Hydrocarbon production from unconventional shale gas reservoirs has become common in the past decade, and there are increasing demands to understand the petrophysical and geomechanical properties of these rocks.

Geomechanical properties of gas shales are required to understand strength and stiffness of such shales, whether they will be brittle enough to initiate fractures within and keep such fractures open or whether they will be ductile, and allow fracture closure and self sealing. A field-scale geomechanical characterization requires understanding the set of rock properties that describe the present-day mechanical (elasto-plastic) behavior under the present day in-situ stress conditions.

Most shale reservoirs depend upon some level of microfractures or natural fractures for enhanced production. Because the general mineralogical properties of shale reservoirs consist primarily of clay minerals such as smectite, a perceived fluid sensitivity led operators to minimize the fluid placed in these reservoirs [1].

Principal stress profiles in a field are related to rock geomechanical properties. These properties play significant role in developing shale assets.

\section{PRINCIPLES OF ROCK MECHANICS}

Stress is a tensor that describes the forces acting on all possible surfaces passing through a given point. In considering a randomly oriented plane of area $\Delta A$ centered on

* AGH University of Science and Technology, Faculty of Drilling, Oil and Gas, Krakow, Poland 
a point $\mathrm{P}$ within a body across which a resultant force $\Delta F$ acts, the stress vector $\sigma$ at that point is defined as:

$$
\sigma=\lim _{\Delta A \rightarrow 0}\left[\frac{\Delta F}{\Delta A}\right]
$$

Strain is a material's deformation (not failure) in response to stress. Consequently, strain (which is either a ratio of lengths or a change of angle) is dimensionless [2].

Straining along an arbitrary direction can be decomposed into two components:

- elongation, defined as:

$$
\varepsilon=\lim _{l \rightarrow 0} \frac{l-l^{*}}{l}
$$

- shear strain, defined as:

$$
\gamma=\tan (\psi)
$$

where $\psi$ is the change of angle between two directions that were perpendicular prior to straining.

Understanding the controls on the elastic properties of reservoir rocks is crucial for exploration and successful production from hydrocarbon reservoirs. Elasticity is known to be the possibility of increasing and decreasing the volume of any fluid or material and is expressed as the ratio of stress to strain. The three main types of deformations are the Young's, Bulk and Shear modulus, [3] where the first one defines the change in length, the second the change in volume and the third the change of angular shape. The elastic modules of a material is primarily described by its Poisson's ration (v) and Young modulus (E).

Young's modulus (or modulus of elasticity, also referred to as stiffness, usually denoted as E) is the ratio of applied stress to resulting strain in the same direction. The static (Young's modulus) and dynamic ( $\mathrm{P}$ - and S-wave modules) elastic parameters generally decrease monotonically with the clay plus kerogen content. The elastic modulus of an object is defined as the slope of its stress-strain curve in the elastic deformation region:

$$
\lambda_{m} \stackrel{\text { def }}{=} \frac{\operatorname{stress}(\sigma)}{\operatorname{strain}(\varepsilon)}=E
$$

The Young's modulus often referred to in gas shale settings is usually determined from seismic data, i.e. it is a dynamic Young's modulus, which may differ from the static Young's modulus determined through lab testing [2].

Poisson's ratio is defined as the negative ratio of transverse to axial strain. When a core sample, or other material, is stretched to an extension or compressed to a contraction in the direction of the applied load, it corresponds to a contraction or extension in a direc- 
tion perpendicular to the applied load. The ratio between these two quantities is Poisson's ratio. In addition, the values of Poisson's ratio for most rocks reported in the literature range from about $0.05-0.25$ :

$$
\nu=-\frac{d \varepsilon_{\text {trans }}}{d \varepsilon_{\text {axial }}}=-\frac{d \varepsilon_{y}}{d \varepsilon_{x}}=-\frac{d \varepsilon_{z}}{d \varepsilon_{x}}
$$

Young's Modulus, also known as the tensile modulus, and Poisson's Ratio are two of the most important rock mechanics values used in hydraulic fracturing (Tab. 1).

\section{Table1}

Young's Modulus and Poisson's ratio values of samples from Baltic Basin in Poland area

\begin{tabular}{|c|c|c|c|c|c|}
\hline & Sample 1 & Sample 2 & Sample 3 & Sample 4 & Sample 5 \\
\hline $\begin{array}{c}\text { Young's } \\
\text { Modulus } \\
{[\mathrm{MPa}]}\end{array}$ & 10479 & 694 & 1266 & 835 & 13647 \\
\hline $\begin{array}{l}\text { Poisson's } \\
\text { ratio }\end{array}$ & $\begin{array}{c}- \\
0.22\end{array}$ & $\begin{array}{c}0.27 \\
-\end{array}$ & $\begin{array}{c}- \\
0.42\end{array}$ & $\begin{array}{c}0.29 \\
-\end{array}$ & $\begin{array}{l}0.14 \\
0.21\end{array}$ \\
\hline
\end{tabular}

Bulk Modulus is another elastic constant, which defines how much energy is required to deform a material by the application of external pressure. This is a special form of compressive stress, in which the applied compressive stress is equal in all directions [6].

Figure 1 present schematic illustration of the relationships between stress, strain and the physical meaning of elastic modules in different types of idealized deformation measurements.

Static elastic and failure properties such as the various elastic modules (Young's, bulk, shear), Poisson's ratio, tensile strength, unconfined compressive strength, cohesive strength, friction coefficient and their anisotropies are required in addition to the magnitude, orientation and anisotropy of the in-situ stress field.

The in-situ stress is local stress state in a given rock mass at depth. The three principal stress components of the local stress state are typically compressive, anisotropic and nonhomogeneous. It is the most important factor controlling hydraulic fracturing. The maximum horizontal stress, minimum horizontal stress and vertical, or overburden, stresses control fracture azimuth, vertical/horizontal orientation, total and directional height growth, surface treating pressure, bottom hole treating pressure, net closure stress and proppant crushing, embedment and fracture cross-sectional width profiles, just to name a few.

These stress states, illustrated in Figure 2, are called faulting regimes and are based on Anderson faulting theory [5]. If the vertical stress is the maximum stress, the regime is normal faulting. If the vertical stress is the intermediate stress, the regime is strike-slip faulting. If the vertical stress is the least stress, then the regime is reverse faulting. 


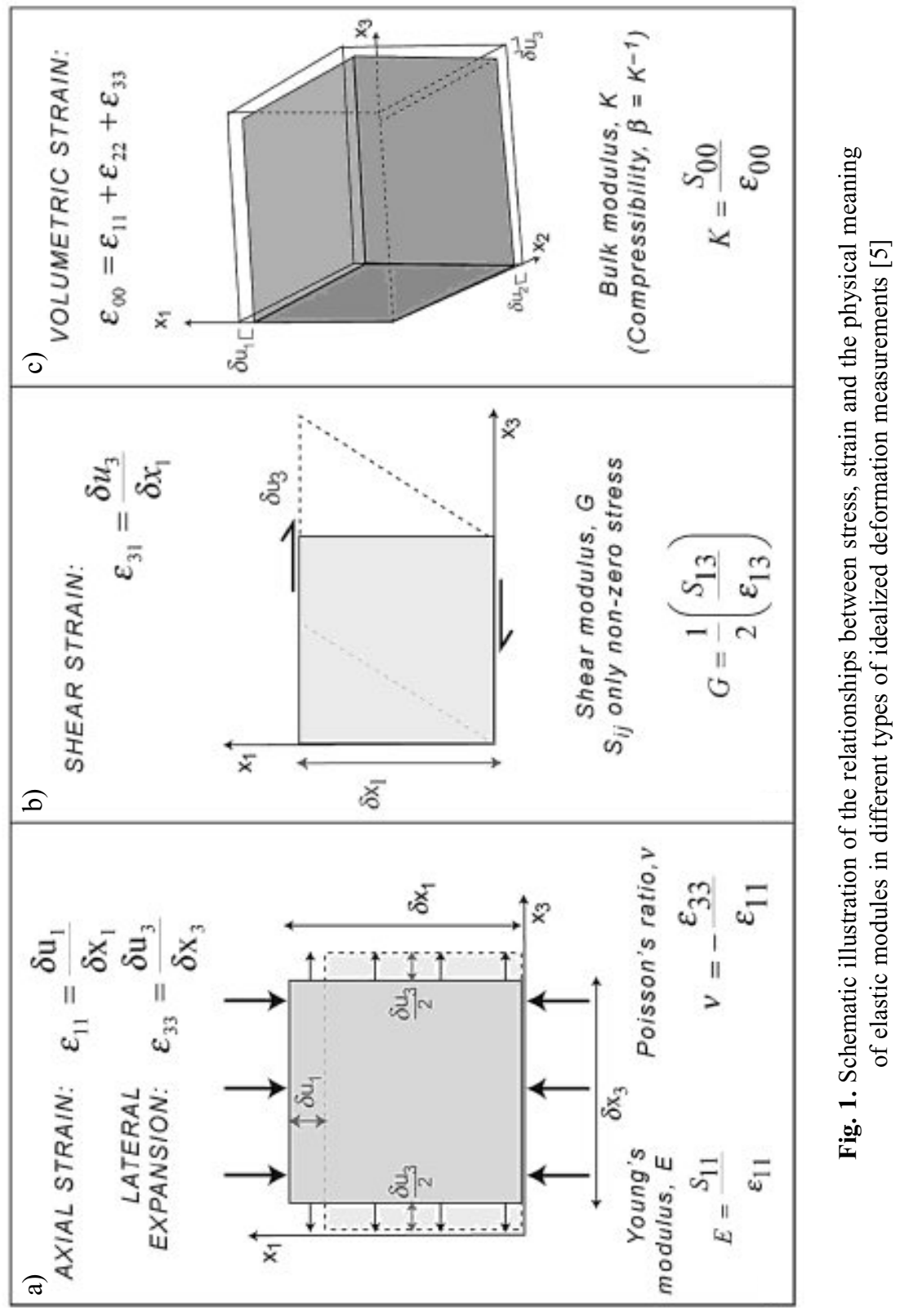




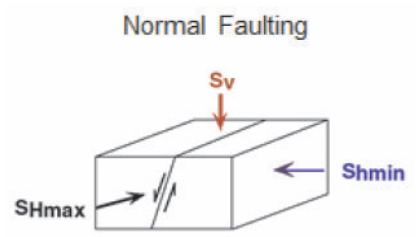

$\mathrm{S}_{\mathrm{V}}>\mathrm{S}_{\mathrm{H} \max }>\mathrm{S}_{\mathrm{hmin}}$

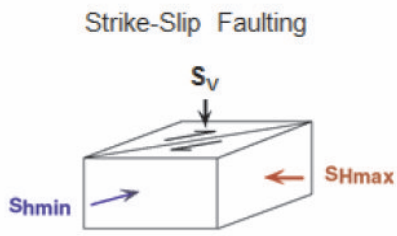

$\mathrm{S}_{\mathrm{H} \max }>\mathrm{S}_{\mathrm{V}}>\mathrm{S}_{\mathrm{hmin}}$

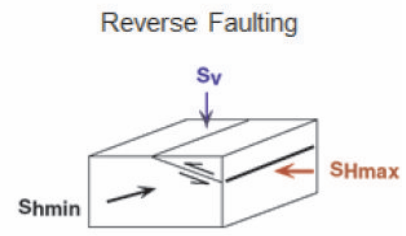

$S_{H \max }>S_{h \min }>S_{V}$

Fig. 2. The three faulting regimes and relative stress magnitudes for them [5]

Mineralogy. Knowledge of formation mineralogy and composition is critically important information when designing the fracturing treatment regardless of whether the formation is pre-dominately sandstone (quartz), fractured shale, limestone or dolomite, or a stratified com-bination of all. Mineral content as determined from powdered X-ray diffraction (XRD) techniques. The primary components of sandstone are quartz, cementing material such as calcite, clay, or silica, and clay (which could be smectite, chlorite, kaolinite, illite or multiple combinations of same) [4]. The primary components of shale are quartz, calcite and clay, the clay often being mixed layered clay, illite-smectite. In Figures 3 and 4 presented mineral composition and petrography of shale rocks.

a)

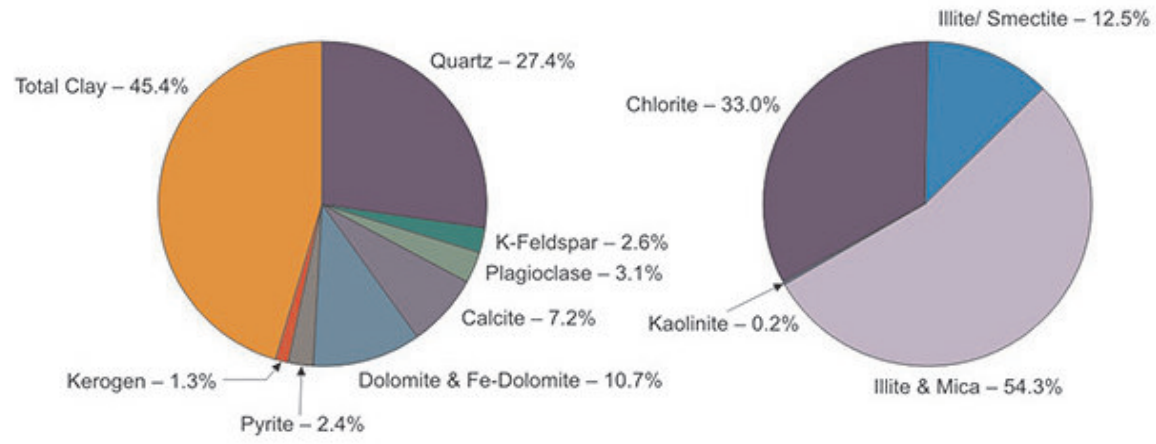

b)

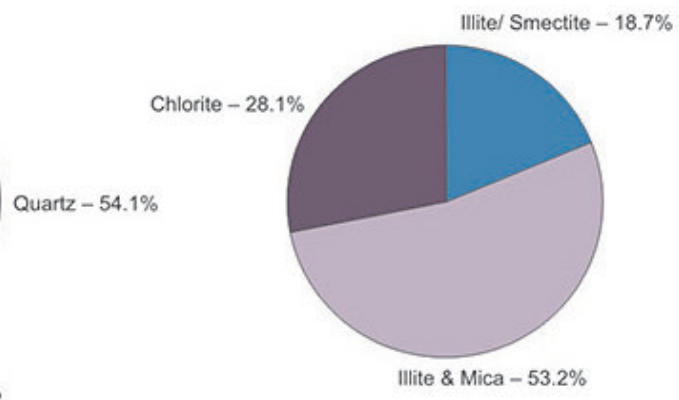

Fig. 3. Mineral composition of lower Paleozoic shale rocks from the Baltic Basin:

a) Upper Ordovician; b) Weprawa, 2012 [9] 

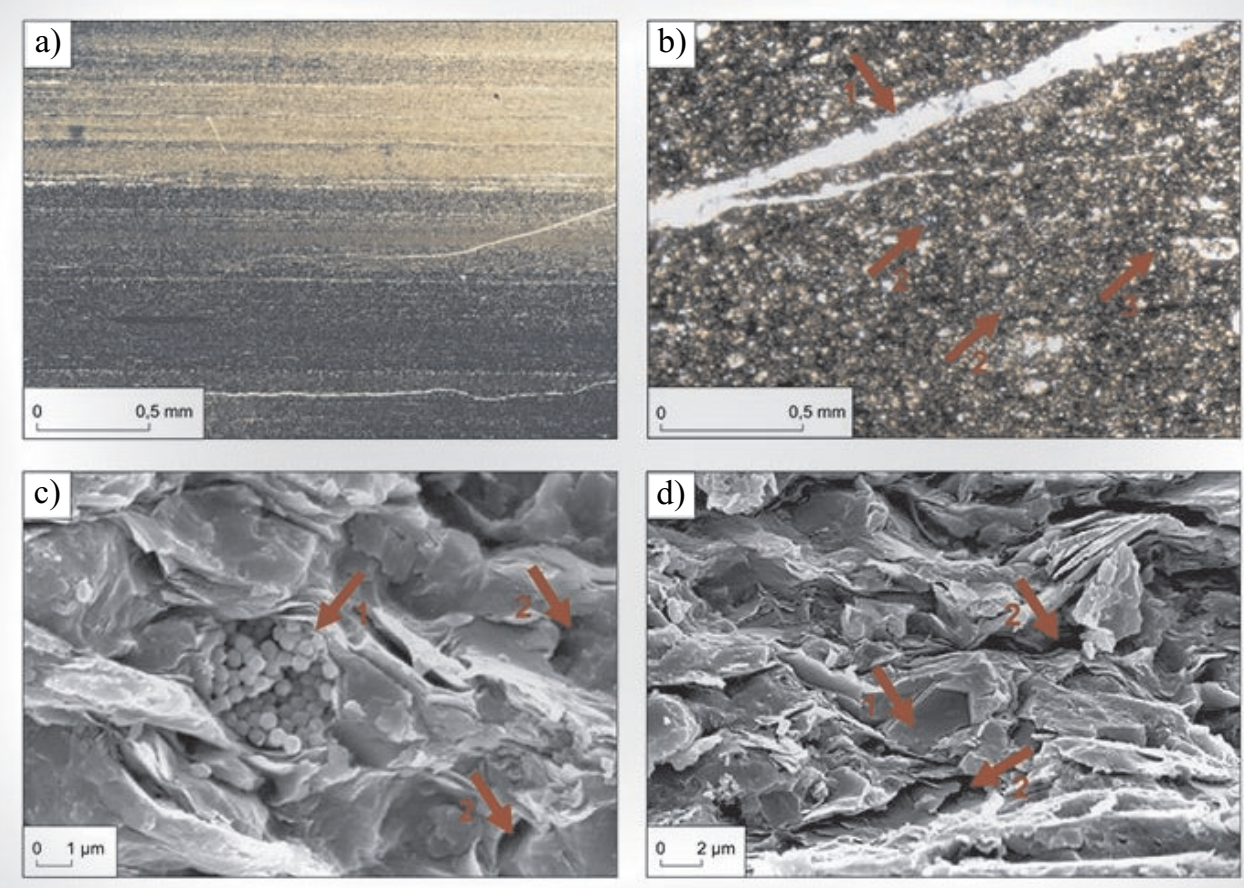

Fig. 4. Petrography of shale rocks (source: Polish Geological Institute)

\section{MAIN CRITERIONS FOR DEVELOPMENT OF SHALE GAS}

The basic criteria for exploration, for the conduct of work for the discovery of new hydrocarbon reserves of shale gas type are as follows [7]:

- High TOC (Total Organic Carbon, average more than $1-2 \%$ by weight).

- Large thickness of the complex is rich in organic matter (more than 30-60 meters, depending on TOC).

- High thermal maturity of shales-more than 1.1-1.3\% Ro (vitrinite reflectance scale), but not greater than $3.5 \%$ Ro.

- Quick burial and heating, and uplift the complex of rock.

- Limited the depth of the bed-below 3500-4500 m, shallower not exceed $1000 \mathrm{~m}$.

- Low level of tectonic deformation of the bed-almost horizontal alignment layers.

- The presence of anomalous pressure.

- The presence of gas and conventional gas deposits in the depositional basin.

- High content of silica in the shale and low content of hydrophilic clay minerals.

Based on data from the literature on the exploration of unconventional shale gas type as the critical value approx. $2 \%$ TOC. But there are also examples of the presence in the US 
shale gas and shale oil in the rocks are characterized by the presence of organic matter down to $<1 \%$ TOC. A very important factor of the search for gas in shale tectonics is gas pollution in layers.

\section{CASE OF STUDY - POLAND, BALTIC BASIN}

Shale gas is currently produced in several basins in USA and Canada. American success in unconventional gas production led to intensive shale gas and tight gas exploration across the world, with Europe being one of the priorities.

During last years the most intensive exploration for shale gas and shale oil globally, except of USA and Canada, took place in Poland. Estimates of shale gas resources in Poland made in recent years have shown a very wide range of results from 1,000 billion $\mathrm{m}^{3}$ (3 Legs Resources) to as much as 5,300 billion $\mathrm{m}^{3}$ (the report prepared for the Energy Information Administration by Advanced Resources International Inc). The three basins in question, where there is potential for commercial exploitation, are: the Baltic Basin (northern), Podlasie Basin (east and east-central), and Lublin (south-east). The oldest formations are the Upper Cambrian to Tremadocian bituminous shale, developed only in the northern part of the onshore Baltic Basin and in its offshore part (Fig. 5).

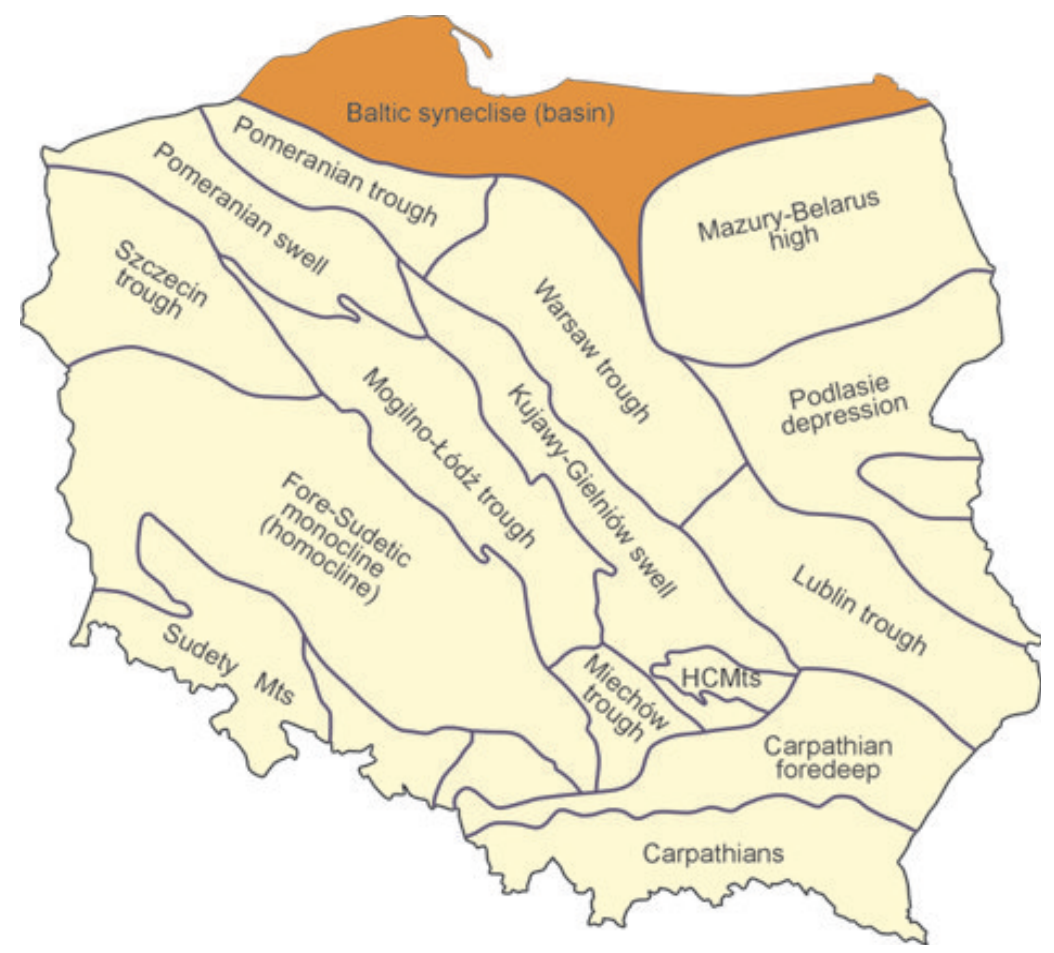

Fig. 5. Location of the Baltic Basin in Poland [8] 
Three potential intervals have been identified for significant unconventional gas accumulations including the Lower Silurian, Ordovician, and Upper Cambrian. The targeted intervals contain a package of thick, laterally extensive, organic rich source rocks in a relatively quiet tectonic setting between 2,000-5,000 meters depth.

This shale contains organic matter with the II type of kerogen. Development of this formations was caused by interaction of several processes, with the main being basin's subsidence, relative sea level changes, basin's bathymetry, organic productivity, rate of detritus supply, geochemical conditions at the sea bottom, mainly oxygenation, activity of organisms penetrating soft sediment, presence of topographic barriers at the sea bottom favoring development of isolated zones with anoxic conditions, sea current configuration and paleoclimatic conditions.

PGNiG SA has begun drilling the first exploration well at Block 29 - Wejherowo concession. Since most of these wells were the very first ones drilled on the concessions, the drilling activity has mostly consisted in collecting core samples for analysis to determine the thickness of the shale, the content of organic matter and silica, porosity, and thermal maturity (reflecting the phase of the transformation of organic material into oil or gas). Simultaneously in the Wejherowo concession seismic survey is being carried out at the moment. Wells drilled on PGNiG's concessions: Lubocino-1 (02.2011), Lubocino-2H (11.2012), Opalino-2 (12.2012), Kochanowo-1 (07.2013), Lubocino-3H (12.2013), Opalino-3 (01.2014), Opalino-4 (04.2014), Tępcz-1 (06.2014) (Fig. 6, Tab. 2).

Most companies are currently at the stage of laboratory evaluation of rocks, accompanied by the interpretation of the research results and borehole measurements [10]. Shale gas reserves are at an initial stage of exploration. To assess the size of unconventional gas resources, it is necessary to drill additional wells, while there is an urgent need for additional geological, physical, chemical and geochemical analysis.

At the turn of 2010 and 2011 Lubocino-1 well was completed (final depth 3,050 m Middle Cambrian) and 738,6 $\mathrm{m}$ of well core was recovered and undergoing analysis at the moment (Fig. 7).

Measured values of Poisson's Coefficient and Young Modulus show more brittle rocks properties in the greater part of perspective interval $(2,550-2,972 \mathrm{~m})$ and increasing their vulnerability to fracturing. Laboratory measured values of $\mathrm{P}$ wave are not in good coherence with compressional wave obtained from wireline logs.

Total clay minerals content according to laboratory analyses variers from 10 to $15 \%$ lower than interpreted shaliness from wireline logs in well Lubocino-1. Quartz content fluctuates between $20-30 \%$. There is also considerable amount of feldspars approx. $10-15 \%$. That causes a big increase in brittleness of these deposits (and as a result tendency to fracturing), especially at the bottom section of Silurian and Ordovician (below 2,550 m). Results of analyses suggest necessity of performance of wide rage laboratory analyses in order to calibrate interpretation of wireline logging (a choice of appropriate interpretation model). Temperature $T_{\max }$ show sufficient thermal maturity of organic matter in Lower Silurian and Ordovician deposits. Laboratory analyses of permeability indicate its good properties especially at 2,550-2,972 $\mathrm{m}$ interval where they reach up to $50 \mathrm{mD}$. Its significant scattering suggests rock matrix permeability as well as fracturability and presence of fractures. Total porosity 
values measured by porosimiter and magnetic resonance analyses correspond well with total porosity interpreted from wireline logs. Effective porosity values measured by NMR analyses do not correlate sufficiently with effective porosity interpreted from wireline logs.

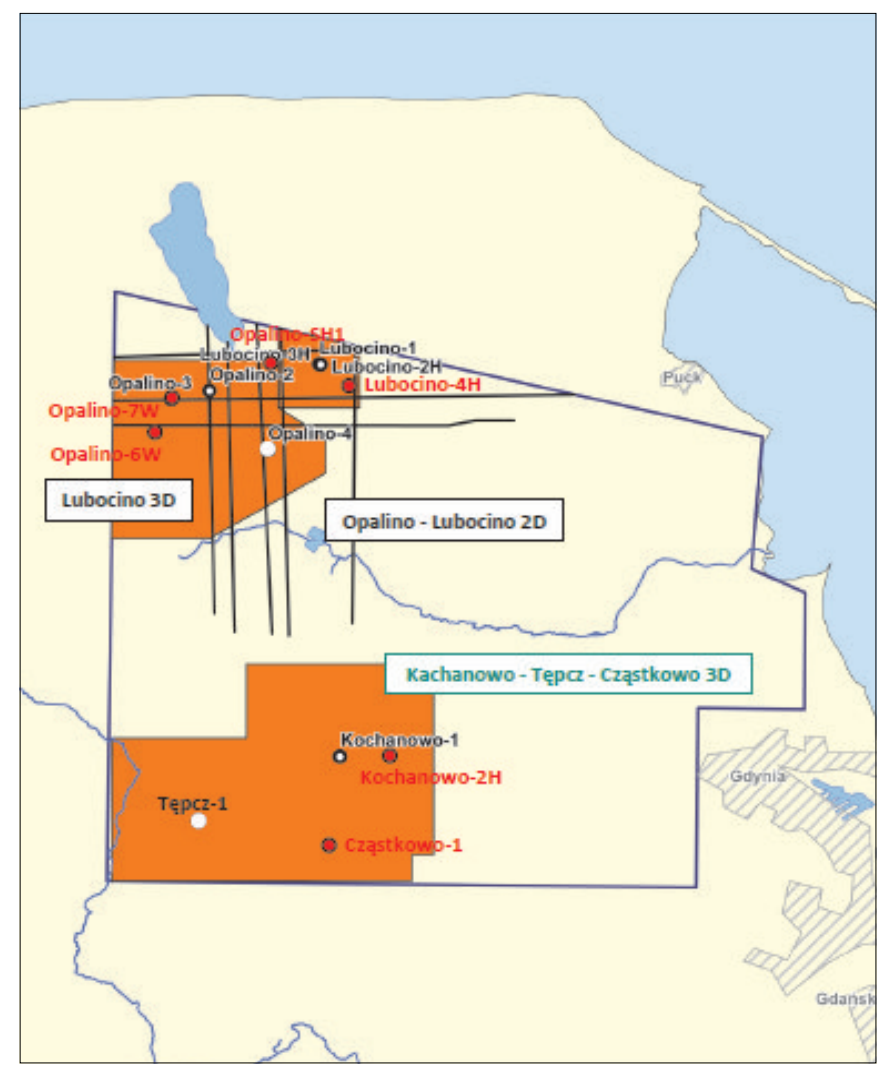

Fig. 6. Location of the Baltic Basin in Poland [8]

Table 2

Wells drilled on PGNiG's concessions

\begin{tabular}{|l|c|c|}
\hline \multicolumn{1}{|c|}{ Well } & Depth [m] & Seismic \\
\hline Lubocino-1 & 3,050 & Opalino - Lubocino 2D \\
\hline Lubocino-2H & 3,980 & Lubocino 3D \\
\hline Lubocino-3H & 3,572 & - \\
\hline Opalino-2 & 3,050 & - \\
\hline Opalino-3 & 3,070 & - \\
\hline Kochanowo-1 & 3,275 & - \\
\hline Opalino-4 & 3,100 & Opalino 3D \\
\hline Tępcz-1 & 3,380 & - \\
\hline
\end{tabular}




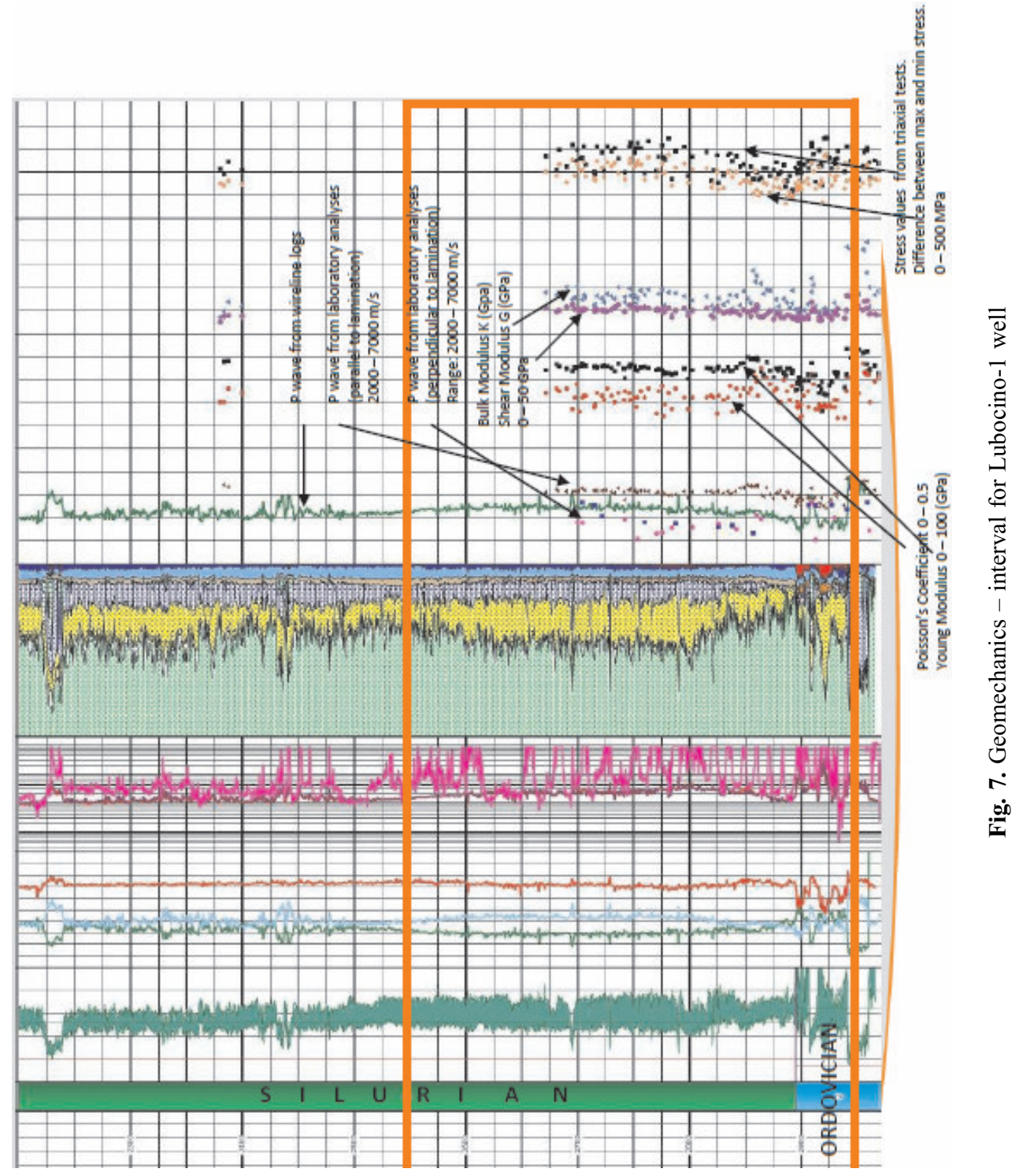


The Polish shale gas boom began in 2011 with extremely buoyant resource estimates based on assumed similarities between the geological properties of Polish and US shale formations. Shale gas exploration activity in Poland has been sluggish so far, with only 39 test wells drilled in 2012, 10 fewer than the 49 wells anticipated by the Environment Ministry (2011 saw only 13 test wells). It is also worth noting that the prospecting made so far in Poland indicates certain differences between local and US shale characteristics, particularly when it comes to "frackability" using the technology developed in the States.

Table 3

Comparison of data for the gas shales in United States and Poland

\begin{tabular}{|l|c|c|c|c|c|}
\hline Gas Shale Basin & Barnett & Monthey & Haynesville & Marcellus & $\begin{array}{c}\text { Baltic Basin } \\
\text { (Poland) }\end{array}$ \\
\hline Depth [ft] & $6,500-8,500$ & $6,500-11,000$ & $11,000-13,000$ & $4,000-8,000$ & $7,000-14,500$ \\
\hline Gross Thickness [ft] & $150-700$ & $1,000-1,400$ & $1200-1300$ & $50-300$ & $500-2,500$ \\
\hline Net Thickness [ft] & $100-600$ & $450-525$ & $200-350$ & $50-250$ & $50-200$ \\
\hline $\begin{array}{l}\text { Thermal Maturity } \\
\text { [\% Ro] }\end{array}$ & $0.8-0.3$ & $2.2-3.8$ & $1.8-2.5$ & $0.7-2.15$ & $1.0-2.6$ \\
\hline $\begin{array}{l}\text { Total Organic } \\
\text { Carbon [\%] }\end{array}$ & 4.5 & $1.0-5.0$ & $0.5-4.0$ & $1.0-5.0$ & $1.0-6.0$ \\
\hline Silica Content [\%] & $35-50$ & $45-60$ & 34 & $20-60$ & $25-63$ \\
\hline Clay Content & $<35$ & - & 33 & $20-35$ & $30-48$ \\
\hline Total Porosity [\%] & $4.0-5.0$ & $2.0-4.5$ & $8-15$ & $1.6-7.0$ & $4-8$ \\
\hline Permeability [nD] & - & $240-450$ & - & - & $>300$ \\
\hline $\begin{array}{l}\text { Gas-In-Place, } \\
\text { BcF/Selection }\end{array}$ & $50-150$ & $130-320$ & $200-250$ & $40-130$ & $40-200$ \\
\hline $\begin{array}{l}\text { Pressure Gradient } \\
\text { [psi/ft] }\end{array}$ & $0.46-0.50$ & 0.65 & $\begin{array}{c}\text { Over } \\
\text { pressured }\end{array}$ & $0.45-060$ & $0.44-0.60$ \\
\hline $\begin{array}{l}\text { EUR per well } \\
\text { [BCF] }\end{array}$ & 2.65 & - & 6.5 & - & $2.25-4.0$ \\
\hline
\end{tabular}

\section{CONCLUSIONS}

The production simulations show the strong dependence on the geomechanical properties of the rock, which affect how the gas transport through the matrix and fractures changes with stress. The increasing significance of shale gas plays has lead to the need for deeper understanding of shale behavior. 
The most important factor for overall fracture design is the in-situ stress field. Stress not only controls or influences most aspects of fracture behavior, but also influences the valuences of both reservoir properties and mechanical properties of rock. The key component of a comprehensive geomechanical model is knowledge of the current state of stress and mineralogy [11].

The largest shale gas resources in Poland may be found in the Baltic Sea basin, in the Nizina Podlaska lowland and the Lubelskie regions. Geology remains the most challenging aspect of the Polish shale industry. Whilst many hoped for shale similar to that found in the US, Polish shale has proved far more problematic, with each play constituting an entirely new geology and thus greater time commitment.

This paper clearly shows the importance of linking the mineralogy, rock mechanics, and geomechanics to determine an unconventional shale play's prospectivity.

\section{REFERENCES}

[1] Economides M., Oligney R., Valko P.: United Fracturing Design. Orsa Press, Texas, 2000.

[2] Zoback M.D.: Reservoir Geomechanics. Department of Geophysics, Stanford University, 2007.

[3] Economides M., Boney C.: Reservoir Stimulation. University of Houston, 2000.

[4] Economides M.J., Martin T.: Modern Fracturing Enhancing Natural Gas Production. ET Publishing, Houston 2007.

[5] Fox A., Snelling P., McKenna J., Neale C., Neuhaus C.: Geomechanical Principles for Unconventional Reservoirs. MicroSeismic, 2006.

[6] Sone H., Zoback M.D.: Mechanical properties of shale-gas reservoir rocks. Part 1: Static and dynamic elastic properties and anisotropy. Geophysics, vol. 78, No. 5, 2013.

[7] Nowicka A.: Gaz z lupków - nowe wyzwanie na obszarze wyniesienia Łeby. PGNiG SA, Oddział w Zielonej Górze, 2012.

[8] Fanning O.: Lewino-1G2: Successful Vertical Frac Leads to Horizontal Well. San Leon Energy, 2014.

[9] Raport nt. uwarunkowania rozwoju wydobycia gazu z polskich formacji tupkowych. Forum Energetyczne, Instytut Nafty i Gazu, 2012.

[10] Kliszcz K.: Gaz tupkowy w Polsce. Aktualny stan poszukiwań. 2013.

[11] Chou Q., Gao J., Somerwil M.: Quicksilver Analysis of Geomechanical Data for Horn River Basin Gas Shales, NE British Columbia, Canada. Resources Canada Inc., SPE 142498, 2011. 